\title{
PERSEBAYA DAN BONEK DALAM KONGLOMERASI JAWA POS
}

\author{
Oleh: \\ Fajar Junaedi \\ (Mahasswa Program Doktor Kajian Budaya dan Media Universitas Gadjah Mada, dosen \\ Ilmu Komunikasi Universitas Muhammadiyah Yogyakarta)
}

Prof. Dr. Heru Nugroho

(Program Doktor Kajian Budaya dan Media Universitas Gadjah Mada)

Dr. Sugeng Bayu Wahyono

(Program Doktor Kajian Budaya dan Media Universitas Gadjah Mada)

\section{Intisari}

Pada awal dekade 1980-an, Jawa Pos adalah sebuah koran yang hampir bangkrut setelah mengalami krisis sejak satu dekade sebelumnya. Pada akhir 1970-an, oplah Jawa Pos mengalami kemerosotan tajam, dan titik nadir Jawa Pos terjadi ketika di tahun 1982, oplahnya tinggal 6.800 perhari. Pemilik Jawa Pos, The Chung Sen memutuskan menjual Jawa Pos kepada kelompok bisnis media Tempo Grafiti. Kelompok bisnis media ini menunjuk Dahlan Iskan sebagai nahkoda baru Jawa Pos. Jawa Pos di bawah kendali Dahlan Iskan mengembangkan jurnalisme olahraga, sebuah praktek jurnalisme yang sering disebut sebagai jurnalisme mainan karena sifatnya yang tidak serius, dengan mengangkat secara massif pemberitaan tentang Persebaya dan Bonek. Persebaya adalah klub sepakbola dari kota Surabaya dan Bonek adalah fans Persebaya. Awalnya, Jawa Pos memanfaatkan Persebaya untuk menaikan oplahnya dengan cara mengalokasikan pemberitaan yang berlimpah tentang klub sepakbola ini, dan sekaligus mereproduksi identitas Bonek bagi fansnya. Bersamaan dengan berlimpahnya pemberitaan tentang Persebaya dan reproduksi terhadap identitas Bonek, Jawa Pos berkembang menjadi koran terkemuka di kota Surabaya pada akhir dekade 1980-an. Sejak dekade 1990-an, Jawa Pos berkembang menjadi koran nasional dan mengembangkan bisnisnya baik di lini media maupun non media. Jawa Pos berkembang menjadi konglomerasi media dan non media di tingkat nasional dengan keberhasilannya melakukan ekspansi bisnis ke berbagai lini media. Di tengah redupnya bisnis media cetak, terutama akibat laju pertumbuhan media daring, Jawa Pos mengembangkan konglomerasinya dengan mengambil alih kepemilikan Persebaya pada awal tahun 2017.

Kata Kunci : Konglomerasi, Jawa Pos, Persebaya, Bonek 


\begin{abstract}
In the early decade of the 1980s, Jawa Pos was a newspaper that almost went bankrupt after a crisis of a decade earlier. In the late 1970s, the Jawa Pos circulation experienced a sharp decline, and the nadir point of Jawa Pos occurred when in 1982, the circulation stayed at 6,800 per day. The owner of Jawa Pos, The Chung Sen decided to sell Jawa Pos to the Tempo Grafiti media business group. This media business group appointed Dahlan Iskan as the new captain of Jawa Pos. Jawa Pos under the control of Dahlan Iskan develops sports journalism, a practice of journalism that is often referred to as toy journalism because of its non-serious nature, by massively lifting the news about Persebaya and Bonek. Persebaya is a football club from the city of Surabaya and Bonek is Persebaya fans. Initially, Jawa Pos utilized Persebaya to raise its circulation by allocating an abundance of news about this football club, and simultaneously reproducing Bonek's identity for his fans. Along with the abundance of news about Persebaya and reproduction of Bonek identity, Jawa Pos developed into a prominent newspaper in the city of Surabaya in the late 1980s. Since the 1990s, Jawa Pos has developed into a national newspaper and has expanded its business both in media and non-media lines. Jawa Pos developed into a media and non-media conglomerate at the national level with its success in expanding its business to various media lines. In the midst of the diminishing print media business, mainly due to the growth rate of online media, Jawa Pos developed its conglomerate by taking over ownership of Persebaya in early 2017.
\end{abstract}

Keywords: Conglomeration, Jawa Pos, Persebaya, Bonek

\title{
A. PENDAHULUAN
}

Persebaya Surabaya, yang selanjutnya cukup disebut dengan Persebaya adalah salah satu klub sepakbola papan atas di Indonesia. Klub ini mencatatkan diri sebagai klub pertama dalam sejarah Liga Indonesia sebagai klub sepakbola yang pertama kali meraih dua kali kampium Liga Indonesia. Dilihat dari sejarahnya, klub sepakbola asal kota Surabaya ini telah berdiri dan berkiprah di lapangan hijau sejak masa kolonial.

Persebaya didirikan oleh Paijo dan Pamoedji pada tanggal 18 Juni 1927 di Surabaya. Salah satu andil terbesar Persebaya dalam sejarah sepakbola Indonesia adalah klub ini menjadi salah satu pendiri Persatuan Sepakbola Seluruh Indonesia (PSSI) bersama perwakilan dari Madiun, Surakarta, Yogyakarta, Magelang, Bandung dan Jakarta (Fahamsyah, $2016:$ 129).

Selain prestasinya di lapangan hijau, Persebaya juga terkenal dengan fansnya yang bernama Bonek. Penelitian terdahulu yang dilakukan oleh Andy Fuller dan Fajar Junaedi (2017) menyebutkan bahwa Bonek adalah varian ultras yang berkembang dalam kultur fans sepakbola di Indonesia. Penelitian tersebut hanya berfokus pada Bonek sebagai fans Persebaya dalam relasinya dengan kultur ultras, belum mengeksplorasi Bonek dalam konteks dan relasinya dengan ekonomi politik media. Penelitian lain tentang relasi media dan olahraga dilakukan oleh Raymod Boyle dan Richard Haynes (2009). Mereka 
menyebutkan bahwa ekspansi olahraga dalam siaran televisi berkembang melalui televisi berbayar yang berimplikasi pada komersialisasi dan komodifikasi olahraga.

Sebagai sebuah identitas yang melekat pada fans Persebaya, Bonek bukanlah sebuah entitas yang sifatnya tunggal. Salah satu perspektif yang bisa digunakan untuk mengkaji tentang identitas Bonek adalah ekonomi politik. Identitas Bonek yang melekat pada suporter Persebaya bisa dilihat dari ekonomi politik media yang dimainkan oleh Jawa Pos, sebuah konglomerasi media yang berpusat di Surabaya. Melalui kajian ekonomi politik kita dapat menganalisis konglomerasi Jawa Pos dan bagaimana konglomerasi Jawa Pos mencaplok Persebaya beserta Boneknya. Sebagaimana yang dikemukakan oleh Vincent Mosco (2009 : 26), bahwa berkaitan dengan ekonomi politik media dapat dilihat melalui empat karakteristik yaitu berdasarkan sejarah dan pertukaran sosialnya, totalitas relasi kuasa, filsafat moral dan praksis. Karakteristik ini akan digunakan sebagai titik pijakan untuk menganalisis Bonek dalam perspektif ekonomi politik.

Titik pijakan analisis ekonomi politik juga didasarkan pada ekonomi politik kritis. Ekonomi politik kritis memberikan perhatian kepada relasi diantara organisasi ekonomi dan politik, sosial dan kehidupan budaya (Golding dan Murdock, 1992 : 18). Maka dengan demikian, klub sepakbola, dalam hal ini adalah Persebaya, dilihat sebagai pabrik (manufacturing football) dengan produknya adalah tontonan yang dijual lewat event dan media kepada Bonek yang menjadi fansnya.

Identitas Bonek yang melekat pada fans Persebaya berkaitan erat dengan masuknya Jawa Pos dalam pengelolaan dan pemberitaan mengenai Persebaya yang berkelindan dengan kepentingan Jawa Pos untuk meraih pasar pembaca di Surabaya. Jawa Pos sebagai sebuah entitas koran besar dan konglomerasi media dimulai sejak pertengahan dekade 1980-an setelah koran ini dipimpin oleh Dahlan Iskan. Segera setelah Dahlan Iskan menahkodai Jawa Pos, koran ini mengalokasikan porsi yang besar bagi besar Persebaya dalam pemberitaanya.

Fenomena menarik terjadi ketika Jawa Pos pada masa itu mulai memberitakan tentang Persebaya, yaitu kontradiksi prestasi antara dua klub yang berada di Surabaya. Kontradiksi prestasi di antara dua klub sepakbola asal Surabaya yaitu Persebaya dan Niac Mitra. Niac Mitra yang bermain di kompetisi Galatama menapaki prestasi tinggi pada tahun 1982 sampai dengan 1985 dengan menjadi juara terutama dengan diperkuat dua pemain asing asal Singapura yaitu David Lee dan Fandi Ahmad. Jika Niac Mitra sedang berprestasi, kondisi sebaliknya terjadi di Persebaya. Pada kompetisi sepakbola Perserikatan tahun 1985, Persebaya berada di posisi kesembilan dari sepuluh peserta. Hanya berada satu tingkat di atas juru kunci tentu saja bukan hal yang menggembirakan bagi klub sepakbola sebesar Persebaya. Pencapaian Persebaya yang berada di papan bawah tentu berbanding terbalik dengan pencapaian prestasinya di tahun - tahun sebelumnya. Tabel berikut ini bisa menjelaskan tentang prestasi Persebaya.

Tabel 1. Prestasi Persebaya sebagai Juara dan Runner Up dalam Kompetisi Tertinggi Sepakbola Indonesia

$\begin{array}{lll}\text { Tahun } & \text { Nama Kompetisi } & \text { Prestasi } \\ 1938 & \text { Perserikatan } & \text { Runner up } \\ 1951 & \text { Perserikatan } & \text { Juara }\end{array}$




$\begin{array}{lll}1965 & \text { Perserikatan } & \text { Runner up } \\ 1967 & \text { Perserikatan } & \text { Juara } \\ 1971 & \text { Perserikatan } & \text { Runner up } \\ 1973 & \text { Perserikatan } & \text { Runner up } \\ 1977 & \text { Perserikatan } & \text { Runner up } \\ 1978 & \text { Perserikatan } & \text { Juara } \\ 1981 & \text { Perserikatan } & \text { Runner up } \\ 1987 & \text { Perserikatan } & \text { Runner up } \\ 1988 & \text { Perserikatan } & \text { Juara } \\ 1990 & \text { Perserikatan } & \text { Runner up } \\ 1996-1997 & \text { Liga Indonesia } & \text { Juara } \\ 1998-1999 & \text { Liga Indonesia } & \text { Runner up } \\ 2003 & \text { Liga Indonesia } & \text { Juara Divisi 1 } \\ 2004 & \text { Liga Indonesia } & \text { Juara } \\ 2006 & \text { Liga Indonesia } & \text { Juara Divisi 1 } \\ 2017 & \text { Liga 2 } & \text { Juara 1 }\end{array}$

Sumber : Informasi didapatkan dari berbagai sumber yang diolah kembali oleh peneliti

Merosotnya prestasi Persebaya menjadi perhatian Dahlan Iskan, pemilik dan pemimpin redaksi koran Jawa Pos. Jawa Pos mulai masuk ke dalam manajemen Persebaya dan berita tentang Persebaya mulai mendapatkan porsi berlimpah di halaman koran Jawa Pos. Masuknya Jawa Pos menandari relasi kuasa antara kepentingan ekonomi Jawa Pos untuk meningkatkan oplah koran, dan kepentingan pengurus Persebaya untuk mengembalikan prestasi klub. Era pertama Jawa Pos masuk dalam manajemen Persebaya ditandai dengan keberhasilan Persebaya menjadi runner up kompetisi Perserikatan pada tahun 1987. Setahun kemudian, Persebaya menjadi juara kompetisi sepakbola Perserikatan. Seiring dengan mulai mengkilapnya kembali prestasi Persebaya, Jawa Pos juga berkembang dengan menggurita sebagai sebuah konglomerasi media dan non media.

\section{B. PEMBAHASAN}

\section{Konglomerasi Jawa Pos, dari Bisnis Media ke Non Media}

Dilihat dari sejarah dan pertukaran sosialnya, kemunculan identitas Bonek bisa dilihat dari awal mula Jawa Pos dipimpin oleh Dahlan Iskan dengan kebijakan redaksional yang mengalokasikan porsi pemberitaan tentang Persebaya secara berlimpah.

Secara historis, Jawa Pos beberapa kali mengalami pergantian kepemilikan. Jawa Pos pertama kali didirikan oleh The Chung Sen alias Suseno Tejo pada 1 Juli 1949 dengan nama Djava-Post, di kota Surabaya. Pada saat mendirikan koran ini, The Chung Sen adalah seorang pegawai bagian iklan sebuah bioskop di Surabaya. Dalam perkembangan selanjutnya, Jawa Pos mengalami pasang surut. Nama Djawa-Post berganti nama menjadi Djawa-Post. Pada akhir 1970-an, oplah Jawa Pos mengalami kemerosotan tajam, dan titik nadir Jawa Pos terjadi ketika di tahun 1982, oplahnya tinggal 6.800 perhari. Akhirnya pemilik Jawa Pos, The Chung Sen saat berusia 80 tahun memutuskan menjual Jawa Pos 
(Wicaksono dkk, 2015 : 17-18, Christiani, 2015 : 205). Kemerosotan oplah Jawa Pos ini terjadi pada saat yang bersamaan dengan jebloknya prestasi Persebaya dalam sepakbola nasional.

Keterlibatan Dahlan Iskan di Persebaya tidak bisa dilepaskan dari kepentingan ekonomi untuk memperluas pasar Jawa Pos di Surabaya. Sampai tahun 1980-an, Surabaya Post adalah koran utama di kota Surabaya. Koran sore ini menguasai pasar koran harian di Kota Surabaya. Jawa Pos sebelum diambil alih oleh Dahlan Iskan adalah sebuah perusahaan keluarga yang hampir mati. Meskipun telah berdiri sejak tahun 1949, Jawa Pos tidak mampu bersaing dengan kompetitornya.

Pengambilalihan kepemilikan Djawa Pos yang berganti nama menjadi Jawa Pos dilakukan oleh Eric Samola, direktur utama Grafiti Pers (Taufani, 2013 : 26). Dahlan Iskan, kepala biro Surabaya Tempo, ditunjuk untuk menghidupkan kembali Jawa Pos. Pada saat mengambil alih Jawa Pos, Tempo sedang mengalami masalah ekonomi sebagai akibat dilarang terbit oleh pemerintah Orde Baru pada bulan April 1982. Pelarangan ini sebagai imbas dari pemberitaannya mengenai kampanye pemilihan umum di tahun tersebut (Hill, 2011 : 106). Pelarangan terbit ini tentu saja menyebabkan tidak adanya pemasukan iklan dari pamasang iklan bagi Tempo. Sebagaimana yang diketahui, pers di masa Orde Baru adalah pers yang tergantung dengan kekuasaan pemerintah melalui berbagai perangkat kekuasaan, seperti yang dilakukan oleh Departemen Penerangan dengan berbagai kebijakannya.

Sensor mandiri, belenggu bahasa, surat peringatan, beredel dan represi - represi brutal lainnya, wajah pers dihiasi dengan muatan pribadi dan aneka peraturan pemerintah yang elastis bak karet. Rasa tersinggung seorang menteri bisa membuat sejumlah surat kabar masuk daftar hitam dan jajaran jurnalisnya bisa dikucilkan dari konferensi pers pemerintah dan sumber informasi lainnya. Dalam memengaruhi industri pers, pemerintah tidak hanya memberikan hukuman tetapi juga menawarkan iming-iming. Bulan Februari 1980, Departemen Penerangan mencanangkan program Koran Masuk Desa (KMD) guna mengenalkan koran ke pelosok desa dan kota kecil. Bermula dari 34 terbitan pers yang digalang pemerintah di tahun 1981, akhirnya tercapailah 43 terbitan. Oleh pemerintah, penerbitan pers ini diberi subsidi untuk memproduksi KMD yang isinya seputar kegiatan pembaca di desa-desa. Pemerintah kemudian memesan koran tersebut dalam jumlah besar untuk disebarluaskan secara gratis ke desa-desa. Upaya ini dimaksudkan untuk menumbuhkan minat baca mereka yang tinggal di pedesaan dan nyaris tidak pernah bersentuhan dengan produk pers, mereka ini adalah 80 persen dari total penduduk Indonesia. Suntikan dana dari pemerintah ini sukses memperpanjang tarikan nafas sejumlah koran daerah dan surat kabar pro pemerintah di beberapa wilayah (Hill, 2011 : 52-53).

Dalam menumbuhkan minat baca, jelas kelihatan adanya intervensi pemerintah. Selain contoh di atas, ini kentara terlihat dari cara pemerintah menggunakan kewenangannya untuk menentukan siapa saja yang bisa duduk di jajaran redaksi. Untuk mengekang pers, bersama mereka yang berada di jajaran legislative membangun jaringan relasi yang rumit dan pelit dengan pihak-pihak dalam struktur organisasi penerbitan. Ini dilakukan seperti dengan melalui Dewan Pers yang didominasi orang-orang yang dekat dengan pemerintah membuat seperangkat pedoman yang mewajibkan surat kabar untuk 
taat pada batasan ruang iklan, dimana iklan maksimal hanya boleh mengisi 35 persen dari jumlah halaman (Hill, 2011 : 53).

Intervensi pemerintah Orde Baru terhadap kehidupan industri pers semakin kuat sejak bulan September 1982. Saat itu Departemen Penerangan mengganti persyaratan Surat Ijin Terbit (SIT) dengan Surat Ijin Usaha Penerbitan Pers (SIUPP). Perubahan ini tidak banyak berarti bagi kebebasan pers, karena penerbitan pers tetap harus tunduk terhadap di bawah aturan pemerintah. Bedanya adalah SIUPP menjangkau sampai pada institusi perusahaan pers. Secara teoritis, peraturan pemerintah berpatokan pada dunia usaha dan seluk beluknya. Ini satu-satunya yang membedakan SIT dan SIUPP, dimana SIT hanya mengacu pada isi pemberitaan sedangkan SIUPP bukan hanya sekadar mengatur isi pemberitaan namun juga menjangkau pada institusi perusahaan. Untuk mendapatkan SIUPP, sebuah badan usaha harus menyiapkan setumpuk dokumen. Selusin lebih surat keterangan dan aneka dokumen perizinan diperlukan, termasuk diantaranya berlembarlembar bukti dukungan dari seluruh organisasi profesi yang dianggap relevan, yaitu Persatuan Wartawan Indonesia dan Serikat Penerbit Suratkabar, baik di tingkat daerah maupun nasional. Yang juga harus ada adalah sejumlah surat izin dari pejabat sipil dan militer beserta surat-surat keterangan pendukung dan bank pemodal dan perusahaan percetakan (Hill, 2011 : 53).

Pengambilalihan kepemilikan Jawa Pos oleh PT Grafiti Pers dari Suseno Tedjo dan Mega Indah terjadi dalam sistem pers Indonesia yang diatur secara ketat oleh pemerintah melalui Departemen Penerangan. Peralihan regulasi dari SIT dan SIUPP menyebabkan pemerintah semakin berkuasa atas hidup matinya perusahaan pers karena bisa menjangkau institusi perusahaan pers. Salah satu poin penting dari SIUPP adalah kewajiban mengalokasikan 20 persen saham untuk karyawan, yang kemudian diterapkan oleh PT Grafiti setelah mengambil alih kepemilikan Jawa Pos.

Pembagian saham Jawa Pos Group, menurut hasil review yang dilakukan oleh Far Eastern Economic adalah sebagai berikut. 40 persen saham dimiliki oleh oleh PT Grafiti Pers. Dari 40 persen ini, sebanyak 16,4 persen adalah miliki keluarga Eric Samola. 40 persen saham diperuntukan untuk direksi dan sisanya sebanyak 20 persen saham untuk karyawan. Dahlan Iskan selain mendapat saham sebagai direksi juga mendapatkan saham tersendiri sebesar 2,4 persen pemberian pribadi Eric Samola (Cohen dalam Christiani, 2015 : 205)

Dahlan Iskan berhasil dengan begitu baiknya mengambil alih Jawa Pos sehingga membuahkan sukses yang tidak pernah terbayangkan oleh rekan - rekannya di Jakarta. Dalam hanya satu dekade, perusahaan yang awalnya tidak dikenal ini melejit menjadi salah satu dari 200 perusahaan terbaik di Indonesia dan menempati peringkat 188 dalam daftar perusahaan pembayar pajak tahun 1990. Tahun 1992, Jawa Pos menjadi surat kabar ketiga terbesar di Indonesia dengan perolehan sirkulasi mencapai 350.000 eksemplar. Jawa Pos menjadi contoh bagaimana 'putra daerah' berhasil merebut pasar nasional. Kelompok Tempo - Grafiti, sebagai induk Jawa Pos, segera memanfaatkan surat kabar tersebut sebagai landasan melakukan ekspansi ke daerah-daerah dimana 'keluarga' tersebut bergabung di bawah kepemimpinan Dahlan Iskan (Hill, 2011 : 107). Keberhasilan Jawa Pos dimulai ketika koran ini berhasil merebut pasar pembaca Surabaya dan Jawa Timur dengan pemberitaan mengenai Persebaya dan suporternya yang dikenal dengan nama 
Bonek. Setelah sukses di Jawa Timur, dengan segera Jawa Pos melakukan ekspansi bisnis ke berbagai daerah.

Jawa Pos kemudian berkembang menjadi sebuah kelompok usaha yang bahkan lebih besar daripada Kelompok Tempo - Grafiti yang membidani kelahirannya. Jawa Pos menjadi salah satu dari dua belas korposari besar yang menguasai bisnis media di Indonesia. Data dalam Media Concentration in Indonesia (Lim, 2012 : 3) menyebutkan bahwa di bidang media kelompok media Jawa Pos memiliki 141 media surat kabar, 12 televisi, 1 radio, 2 majalah, 11 tabloid, 1 media daring dan versi digital. Selain itu Jawa Pos memiliki bisnis di luar media, seperti power plant, pabrik kertas dan bisnis telekomunikasi (Lim, 2012 : 5). Jaringan konglomerasi bisnis media cetak Jawa Pos di bawah payung Jawa Pos News Network (JPNN) menjadi jaringan koran terbesar di Indonesia, yang bermula dari penerbitan Radar, sebuah suplemen berita lokal di berbagai kota (Nugroho, Putri dan Laksmi, 2012 : 16).

Awal konglomerasi bisnis Jawa Pos dimulai dengan pembelian saham berbagai surat kabar dan mengambil alih kepemilikan media di berbagai daerah dan kemudian menyatukannya di bawah payung Radar (Nugroho, Putri dan Laksmi, 2012 : 48). Jawa Pos membeli sejumlah saham dan mengambil alih Manuntung di Balikpapan dan Cahaya Siang di Manado. Kemudian Jawa Pos yang telah bermetamorfosis menjadi kelompok bisnis media membangun kerjasama dengan harian Akcaya di Pontianak, Mercusuar di Palu, Fajar di Makasar, Suara Maluku di Ambon, Suara Nusa di Mataram Nusa Tenggara Barat, Riau Pos di Pekanbaru, Cendrawasih Post di Jayapura, Batam Post di Batam, Independent di Jambi, Palangkaraya Pos (kemudian berganti nama menjadi Kalteng Pos) di Kalimantan Tengah dan sebuah harian baru di Bengkulu bernama Semarak (Hill, 2011:107).

Selain melakukan ekspansi bisnis ke luar Jawa, Jawa Pos juga mengelola bisnis berbagai media di Surabaya. Mereka mengelola harian bisnis bernama Suara Indonesia. Jawa Pos juga menggandeng majalah hiburan tiga bulanan yang terkenal dengan jurnalisme kuning yang sensasional bernama Liberty, majalah anak - anak bernama Mentari Putera Harapan dan harian Karya Darma yang ditujukan sebagai koran pembangunan desa dan mingguan Dharma Nyata. Di Surakarta, kelompok bisnis Jawa Pos menarik tabloid berbahasa Jawa bernama Jawa Anyar. Atas dasar pertimbangan sosial, kelompok ini juga mengasuh manajemen sebuah penerbitan koran pro - Golkar bernama Bhirawa, meskipun dikabarkan bahwa koran ini tidak membawa keuntungan apapun bagi kepentingan bisnis Jawa Pos. Pada bulan Oktober 1991, kelompok Jawa Pos menerbitkan surat kabar mingguan yang menyasar segmen pembaca olahraga bernama Kompetisi dan menarik masuk harian Surabaya Memorandum yang berkubang hutang pada bulan Juli 1992 melalui pembelian saham sebanyak 50 persen (Hill, 2011 : 107).

Kesediaan Jawa Pos untuk ikut mengelola harian Bhirawa yang tidak menguntungkan secara ekonomi memerlihatkan kepentingan Dahlan Iskan untuk mendapatkan perlindungan dari pemerintah Orde Baru. Harus dipahami konteks politik media di masa Orde Baru yang sangat represif terhadap media massa yang melakukan kritik keras terhadap pemerintah. Dengan jargon jurnalisme pembangunan, pemerintah Orde Baru terutama dengan pelaksananya adalah Departemen Penerangan, membatasi kritik dari media massa. Tempo yang awalnya menjadi induk Jawa Pos dan tempat berkarier Dahlan Iskan sebelum ditugaskan menahkodai Jawa Pos pernah tersandung masalah dengan 
pemerintah Orde Baru. Di tahun 1982, majalah Tempo pernah dilarang terbit karena pemberitaan tentang pemilu. Puncak ketegangan majalah Tempo dan pemerintah Orde Baru terjadi ketika Tempo memberitakan impor kapal perang eks Jerman Timur di tahun 1994. Tempo dicabut Surat Ijin Usaha Penerbitan Pers (SIUPP) - nya oleh Menteri Penerangan Harmoko.

Setelah sukses mengelola bisnis media cetak, terutama koran, Jawa Pos mengembangkan usaha bisnis di sektor di sektor hulu percetakan koran dengan membangun pabrik kertas di kota Gresik, sebuah kota yang tidak jauh dari Surabaya. Pabrik kertas yang diberi nama PT Adiprima Sura Perinta tersebut mampu memproduksi kertas koran dengan kapasitas 450 ton per hari (Wicaksono dkk, 2015 : 19).

Selanjutnya konglomerasi media dan non media Jawa Pos berkembang dengan pesat. Tabel berikut ini memerlihatkan konglomerasi media Jawa Pos.

Tabel 2. Konglomerasi Bisnis Media Jawa Pos Group.

\begin{tabular}{|c|c|c|}
\hline $\begin{array}{l}\text { Media } \\
\text { Surat kabar }\end{array}$ & Lokasi & \multirow{2}{*}{$\begin{array}{l}\text { Nama } \\
\text { Metro Aceh Rakyat Aceh }\end{array}$} \\
\hline \multirow[t]{14}{*}{ Surat kabar } & Nangroe & \\
\hline & Darussalam & \\
\hline & Bali dan & Radar Bali, Lombok Pos, Timur Ekspres \\
\hline & \multicolumn{2}{|l|}{ Tenggara } \\
\hline & Sumatera Utara & $\begin{array}{l}\text { Sumut Pos, Pos Metro Medan, Metro Siantar, } \\
\text { Metro Asahan, Metro Tapanuli }\end{array}$ \\
\hline & Kalimantan Barat & $\begin{array}{l}\text { Pontianak Pos, Harian Equator, Metro } \\
\text { Pontianak, Kun Dian Ri Bao, Kapuas Pos, } \\
\text { Metro Singkawang, Metro Ketapang }\end{array}$ \\
\hline & $\begin{array}{l}\text { Riau dan Kepualauan } \\
\text { Riau }\end{array}$ & $\begin{array}{l}\text { Riau Pos, Pekanbaru Pos, Pekanbaru MX, } \\
\text { Dumai Pos, Batam Pos, Pos Metro Batam, } \\
\text { Tanjungpinang Pos }\end{array}$ \\
\hline & Kalimantan Tengah & Kalteng Pos, Radar Sampit \\
\hline & Sumatera Barat & Padang Ekspress, Pos Metro Padang \\
\hline & Kalimantan Timur & $\begin{array}{l}\text { Kaltim Pos, Metro Balikpapan, Samarinda Pos, } \\
\text { Radar Tarakan }\end{array}$ \\
\hline & Jambi & $\begin{array}{l}\text { Jambi Independent, Jambi Ekspres, Pos Metro } \\
\text { Jambi, Radar Bute, Bungo Pos, Radar Tanjab, } \\
\text { Jambi Star, Radar Sarko, Sarolangun Ekspres, } \\
\text { Kerinci Pos, Radar Kerinci }\end{array}$ \\
\hline & \multirow{2}{*}{$\begin{array}{l}\text { Kalimantan Selatan } \\
\text { Sumatera Selatan }\end{array}$} & Radar Banjarmasin \\
\hline & & $\begin{array}{l}\text { Sumatera Ekspres, Palembang Pos, Radar } \\
\text { Palembang, Linggau Pos, Prabumulih Pos, } \\
\text { Oku Ekspres, Lahat Pos, Harian Banyuasin, } \\
\text { Palembang Ekspres, Enim Ekspres, Ogan } \\
\text { Ekspres }\end{array}$ \\
\hline & Sulawesi Utara & $\begin{array}{l}\text { Manado Pos, Posko Manado, Tribun Sulut, } \\
\text { Radar Kotabunan }\end{array}$ \\
\hline
\end{tabular}


Bengkulu

Gorontalo

Bangka Belitung

Sulawesi Tengah

Lampung

Sulawesi Barat

Daerah Khusus Ibukota

Jakarta

Sulawesi Tenggara

Banten

Sulawesi Selatan

Jawa Barat

Maluku

Maluku Utara

Yogyakarta

Jawa Tengah

Jawa Timur

Papua

Majalah Jawa Timur

Tabloid Jawa Timur

Radio Sulawesi Selatan

Televisi Berbagai kota
Rakyat Bengkulu, Bengkulu Ekspres, Radar Selatan, Radar Lat Permai

Gorontalo Pos, Tribun Gorontalo

Bangka Belitung Pos

Radar Sulteng, Luwuk Pos

Radar Lampung, Rakyat Lampung, Radar Metro, Radar Tuba, Radar Lampung Tengah,

Radar Lampung Barat, Radar Lampung Selatan, Radar Trenggamus, Radar Kotabumi Radar Sulbar

Indopos, Rakyat Merdeka, Lampu Hijau, Non Stop, Guo Ji Ri Bao, Indonesia Bisnis Today

Kendari Pos, Kendari Ekspres

Satelit News, Tangsel Pos, Tangerang Ekspres, Radar Banten, Banten Raya Pos

Fajar, Berita Kota Makasar, Pare Pos, Palopo Pos, Ujungpandang Pos, Radar Baubau, Radar Bulukumba, Radar Bone

Radar Bandung, Radar Cirebon, Radar Tasikmalaya, Radar Bogor, Pasundan Ekspres, Karawang Ekspres, Radar Sukabumi, Radar Indramayu, Radar Kuningan, Radar Majalengka

Ambon Ekspres, Radar Ambon

Malut Pos

Radar Yogya

Radar Semarang, Radar Solo, Harian Meteor, Radar Tegal, Radar Banyumas, Radar Kudus, Radar Pekalongan

Jawa Pos, Radar Surabaya, Radar Mojokerto, Radar Malang, Malang Pos, Radar Bromo, Radar Banyuwangi, Radar Tulungagung, Radar Bojonegoro, Radar Jember, Radar Kediri, Radar Madiun, Radar Madura, Harian Bangsa, Rek Ayo Rek, Memorandum Cendrawasih Pos, Radar Timika

Mentari, Liberty

Posmo, Nyata, Koki, Ototrend, Agrobisnis, Komputek, Nurani, Zigma, Gloria, Selera, Cantik, Ultima, Otomodify, Burung, Omega

Fajar FM Makasar

JTV, JakTV, SBO TV, Riau TV, Banten TV, Bogor TV, Padang TV, Batam TV, Pal TV, Pont TV, Fajar TV, Simpanglima TV, 
Daring

Malioboro TV, Padjajaran TV, CB Channel, Radar TV, Jambi TV, Balikpapan TV, Samarinda TV, Radar Cirebon TV, Triarga TV, Mahkamah Konstitusi TV

Jawapos.co.id, jppn mobile, jppn online, versi digital atau berbayar

Sumber : Lintang Citra Christiani (2015); Nugroho, Putri dan Laksmi (2012).

Tabel 3. Konglomerasi Bisnis Non Media Jawa Pos Group

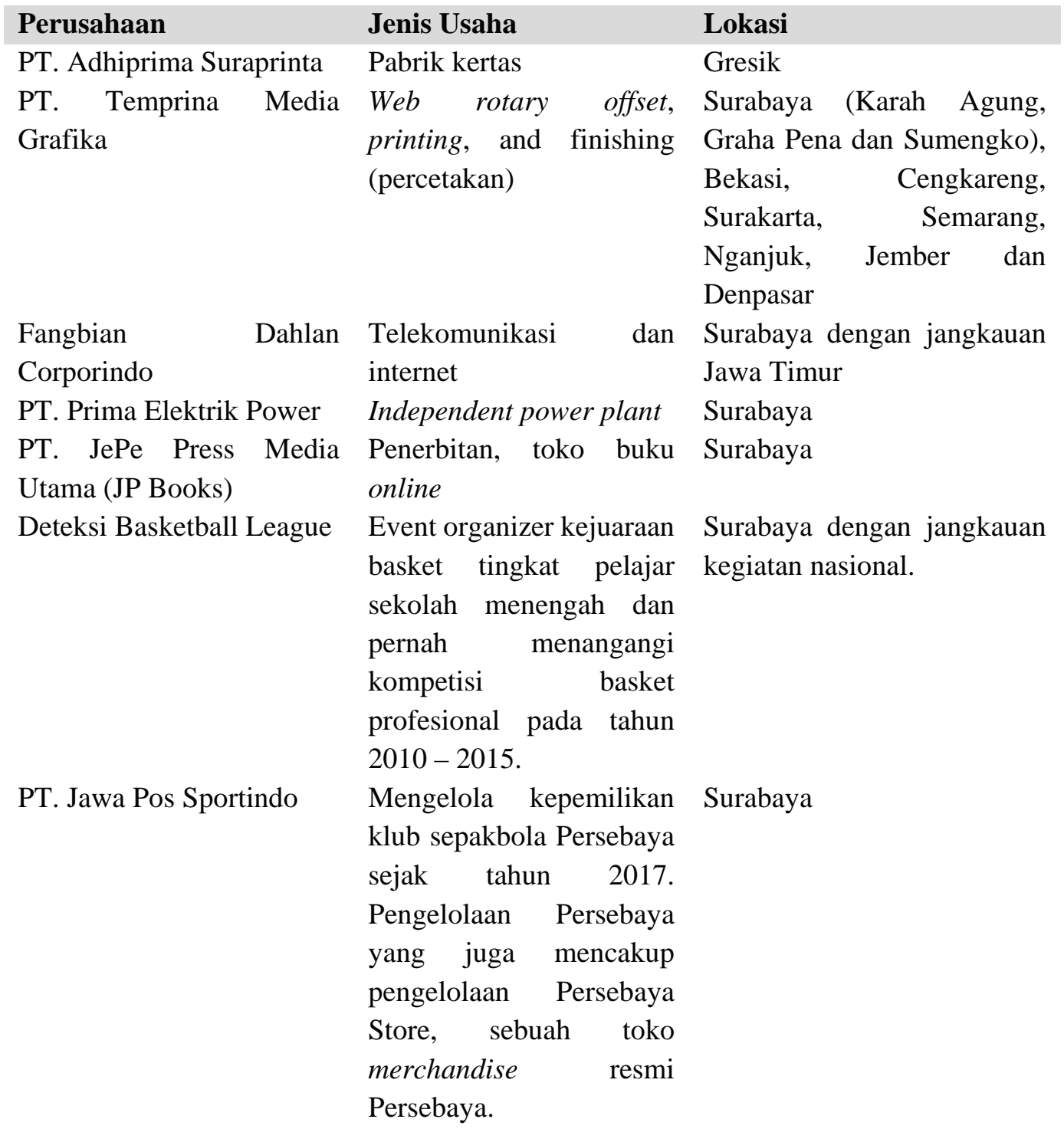

Sumber : Lintang Citra Christiani (2015), Nugroho, Putri dan Laksmi (2012) dengan tambahan data terbaru dari peneliti.

Keberhasilan Jawa Pos membangun dan mengembangkan konglomerasi medianya, sebagaimana yang ditunjukan dengan data-data di atas, dianggap sebagai best practices dalam industri media. Dari koran beroplah kecil dan terbit di Surabaya, menjadi koran dengan jaringan terbesar di Indonesia. Sukses secara bisnis, berdampak pada 
penguatan kredibilitas dan popularitas diri pemilik dan guru jurnalistik semua awak Jawa Pos, Dahlan Iskan (Wicaksono dkk, 2015 : 17).

Setelah sukses mengembangkan konglomerasi di ranah media, Jawa Pos secara agresif mengembangkan gurita konglomerasinya dalam bisnis non media. Mengangkat pemberitaan tentang sepakbola selain bermanfaat bagi Jawa Pos secara ekonomi, terutama dengan pemberitaan tentang Persebaya dan Bonek secara massif, juga menguntungkan Jawa Pos secara politik. Berbeda dengan pemberitaan sosial dan politik yang rentan mengusik penguasa Orde Baru, pemberitaan olahraga dianggap tidak membahayakan kepentingan politik pemerintah Orde Baru. Sepakbola, seperti juga berbagai kecabangan olahraga yang lain, dianggap sebagai 'toy department', a bastion of easy living, sloppy journalism and 'soft' news dalam jurnalisme profesional (Boyle, 2006:12).

Hal ini berarti bahwa berita olahraga bukanlah suatu berita yang berat melainkan berita yang halus, ringan, dan seperti permainan. Kendati merupakan berita santai, namun rubrik ini membawa implikasi penting bagi perkembangan sebuah negara. Olahraga memunculkan fanatisme dari komunitas tertentu yang berpengaruh pada sebuah identitas (Pramesthi, 2014 : 78). Dalam hal relasi Jawa Pos dan Persebaya, identitas ini adalah identitas Bonek. Pengambilalihan saham Persebaya oleh Jawa Pos semakin mengukuhkan Persebaya sebagai industri olahraga, yang sekaligus berarti menempatkan fans sebagai konsumen.

Relasi antara olahraga dan media telah menjadi hubungan yang sifatnya komersial dan budaya yang menentukan bagi kedua industri pada awal abad kedua puluh satu. Media telah mengubah olahraga dari sifatnya yang amatir menjadi industri yang diperdagangkan secara komersial, sementara olahraga telah menyampaikan khalayak dan pendapatan iklan ke media. Cakupan olahraga di televisi pada khususnya telah menciptakan produk yang akan dikonsumsi oleh audiens, dijual oleh klub dan liga, dibeli dan dijual oleh organisasi media dan dimanipulasi oleh pemasang iklan (Nicholson, 2007 : 10). Masuknya Jawa Pos dalam manajemen Persebaya yang ditandai dengan pengambilalihan saham Persebaya semakin mengukuhkan fenomena ini dalam relasi olahraga dan media di Indonesia.

Dalam praktek jurnalisme olahraganya, Jawa Pos mengalokasikan pemberitaan yang berlimpah tentang Persebaya dan Bonek. Persebaya yang di awal dekade 1980-an prestasinya terpuruk, justru mendapatkan porsi pemberitaan yang berlimpah dengan alasan agar kembali mampu bersaing dalam sepakbola Indonesia. Persebaya diglorifikasi oleh Jawa Pos dalam pemberitaannya dengan diberi julukan Green Force. Seiring dengan glorifikasi terhadap Persebaya, fans Persebaya diberi julukan oleh Jawa Pos dengan nama Bonek sebagai bentuk glorifikasi terhadap fans Persebaya. Glorifikasi ini semakin diperkuat dengan menampilkan Bonek dalam sebuah visual seorang laki-laki berambut panjang dengan ikat kepala dengan mimik mulut sedang berteriak laksana seorang pahlawan di medan perang. Ikat kepala tersebut bisa bertuliskan Persebaya atau Green Force atau Bonek. Visual yang diproduksi oleh Jawa Pos tersebut dinamakan sebagai wong mangap (orang yang membuka mulut). Visual yang terus direproduksi dalam pemberitaan Jawa Pos dalam pemberitaannya dengan menjadikan wong mangap sebagai caption berita tentang Persebaya. 


\section{KESIMPULAN}

Bangkitnya imperium bisnis Jawa Pos bermula dari pengambilalihan kepemilikan Jawa Pos pada awal dekade 1980-an oleh kelompok Tempo Grafiti. Dahlan Iskan, kepala biro majalah Tempo Jawa Timur, yang diserahi tugas untuk membangkitkan Jawa Pos melakukan langkah yang brilian. Alih-alih memperbesar porsi berita politik dan menampilkan jurnalisme anjing penjaga (watch dog journalism) yang keras dalam mengkritik pemerintah, Dahlan Iskan justru mengembangkan jurnalisme olahraga melalui Jawa Pos. Jurnalisme olahraga yang tidak serius dibandingkan dengan jurnalisme politik mengamankan Jawa Pos dari ancaman rezim di masa Orde Baru dan sekaligus berhasil membangun pasar pembaca Jawa Pos di kalangan fans Persebaya.

Berlimpahnya porsi pemberitaan Jawa Pos tentang Persebaya dan Bonek telah meningkatkan oplah koran ini di Jawa Timur. Dengan modal oplah yang tinggi di Jawa Timur, Jawa Pos kemudian berkembang menjadi konglomerasi media di tingkat nasional. Jawa Pos yang berkembang di era 1990-an sebagai koran terbesar di luar Jakarta mengembangkan koran-koran satelitnya, yang umumnya dinamakan dengan Radar. Korankoran daerah Jawa Pos mendapatkan kesempatan berkembang lebih pesat ketika reformasi di tahun 1998 membuka kesempatan otonomi daerah yang berimplikasi pada meningkatnya dinamika pemberitaan di daerah.

Kesuksesan Jawa Pos dalam konglomerasi koran berkembang ke bisnis yang lain. Dalam bisnis media cetak, Jawa Pos mengembangkan berbagai majalah dan tabloid. Jawa Pos kembali sukses dengan bisnis media cetak tabloid dan majalah. Sukses yang dilanjutkan pada bisnis media penyiaran. Diawali dengan pendirian JTV, Jawa Pos mengembangkan berbagai stasiun televisi lokal di daerah lain.

Di ranah non media, Jawa Pos mengembangkan bisnis pabrik kertas, percetakan dan pembangkit listrik. Konglomerasi bisnis ini awalnya ditujukan untuk menyokong bisnis utama Jawa Pos di ranah media cetak, namun dalam perkembangannya kian menggurita sebagai bisnis yang menguntungkan bagi Jawa Pos. Jawa Pos mulai terjun ke bisnis olahraga ketika mendirikan Deteksi Basketball League, sebuah kompetisi basket amatir bagi pelajar sekolah menengah. Meskipun basket bukan olahraga paling populer di Indonesia, setidaknya jika dibandingkan dengan sepakbola, Jawa Pos ternyata sukses mengemas basket menjadi entitas bisnis yang menjanjikan.

Pada awal tahun 2017, Jawa Pos mengambil alih kepemilikan saham di PT. Persebaya Indonesia melalui PT. Jawa Pos Sportindo. Dengan kepemilikan saham di Persebaya, Jawa Pos mengulang kisah lama relasinya dengan Persebaya di awal dekade 1980-an. Bedanya jika di awal tahun 1980-an, Jawa Pos tidak dalam posisi sebagai pemilik Persebaya, maka sejak tahun 2017 Jawa Pos resmi menjadi pemilik Persebaya. Situasi yang dihadapi oleh Jawa Pos pada kedua era ini hampir mirip. Situasi yang dihadapi Jawa Pos di awal dekade 1980-an adalah oplah yang rendah dan persaingan dengan Surabaya Post, koran sore utama di Jawa Timur pada masa tersebut. Sedangkan situasi yang dihadapi Jawa Pos di tahun 2017 adalah tantangan dari perkembangan media daring (online) yang menggerus bisnis media cetak. Dengan memiliki Persebaya, Jawa Pos berusaha mendapatkan pembaca setia yaitu para fans Persebaya. Bonek menjadi konsumen dari 
Persebaya di bawah kendali PT. Jawa Pos Sportindo sekaligus sebagai konsumen koran Jawa Pos.

\section{DAFTAR PUSTAKA}

Boyle, Raymond (2006). Sports Journalism, Context and Issues. London, Sage Publication Boyle, Raymond dan Haynes, Richard (2009). Power Play: Sport, The Media and Popular Culture, Second Edition. Edinburg, Edinburg University Press

Christiani, Lintang Citra (2015). Spasialisasi Grup Media Jawa Pos, dalam Jurnal Ilmu Komunikasi Volume 12, Nomor 2, Desember 2015

Fahamsyah, Miftakhul (2015). Mencintai Sepakbola Indonesia Meski Kusut. Yogyakarta, Indie Book Corner

Fuller, Andy dan Junaedi, Fajar (2017). Andy Fuller \& Fajar Junaedi (2017): Ultras in Indonesia: conflict, diversification, activism, Sport in Society, DOI: 10.1080/17430437.2017.1300392

Golding, Peter dan Murdock, Graham (1997). The Political Economy of Media. Chentelham, Edward Egar Publising

Hill, David T. (2011). Pers di Masa Orde Baru. Jakarta, LSPP

Mosco, Vincent (1998). The Political Economy of Communication : Rethinking and Renewal. London, Sage

Nicholson, Mattew (2007). Sport and The Media : Managing The Nexus. Amsterdam, Elsevier

Nugroho, Yanuar ; Putri, Dinita Andriani dan Laksmi, Shinta (2012). Mapping the landscape of the media industry in contemporary Indonesia. Report Series. Engaging Media, Empowering Society: Assessing media policy and governance in Indonesia through the lens of citizens' rights. Research collaboration of Centre for Innovation Policy and Governance and HIVOS Regional Office Southeast Asia, funded by Ford Foundation. Jakarta: CIPG and HIVOS

Pramesti, Olivia Lewi (2014). Olah Raga, Media dan Audiens Perspektif Media Lokal dalam Meliput Isu Olahraga, dalam Junaedi, Fajar ; Satyabharata, Bonnaventura dan Budi, Setyo [ed] (2014). Sports, Komunikasi dan Audiens : Arena Olah raga dalam Diskursus Ekonomi-Politik, Bisnis dan Cultural Studies . Yogyakarta Aspikom - Fikom Untar - Prodi Ilmu Komunikasi UAJY

Taufani, B. (2013). Jurus Mabuk Dahlan Iskan. Yogyakarta, Buku Pintar 